\title{
Address to the World Bank Sociological Group
}

\author{
Huw Evans
}

\section{Introduction}

I feel myself to be an outsider amongst you: I am a macroeconomist by background, having worked in the UK Treasury for many years. Yet I have become convinced in my time at the World Bank of the importance of understanding the social context of the Bank's work, and the social impact of Bank lending, especially because of the UK ODA's experience in this field. As an Executive Director at the IMF too, I have gained important insights into how that institution uses its Board more effectively, with more cooperation, and much greater partnership between the Board and management.

\section{Why Does the Bank Need Social Analysis?}

Let me explain a little more about why the Bank needs social analysis. Firstly, I start from the position that the Bank's mandate is economic development: other social objectives as such are outsides its mandates. While most of our governments have signed up to a range of social objectives unilaterally or as part of international agreements, it is not the job of the Bank to help countries achieve all of them. It is the Bank's job to help poor people improve their standard of living, and more generally to promote economic development. Article IV, section 10 states that "only economic considerations shall be relevant to their [i.e. our] decisions". I am convinced that this apparently narrow focus is one of the reasons why the Bank has many successes.

Some of my colleagues who represent borrowing countries sometimes get concerned when we talk about social issues in the Board, because they fear that the Bank will try to impose social norms. The Bank must be interested in social relations insofar as they relate to economic development. A clear understanding on this will go a long way to reducing resistance in the Board to the examination of social issues. For example, this chair pressed for a long time to get agreement to a 
policy on gender, not as a goal in its own right, but because it is clear that the different roles of men and women affect the success of development assistance, and the different access to resources of men and women affects their access to development investments. Thus, putting more investment into education without addressing the barriers to women's participation would be economically, as well as socially, inefficient. Once the evidence for this was clearly presented to the Board, the policy received broad support. It would never have achieved this if we had based our arguments on women's rights alone, important as these are.

Increasingly, external criticism is focusing on social rather than environmental impacts; e.g. resettlement; indigenous groups; health user fees etc. This has already proved damaging to the Bank: e.g. Oxfam/Christian Aid etc. get a lot of publicity in the UK for campaigns criticizing the social impact of World Bank adjustment lending, not all of it valid. The Bank needs to learn from the past and develop social procedures now, to defend the Bank from vulnerability to criticism in this area. This will be good for the Bank's clients, in terms of better assistance, as well as good for the prospects of maintaining shareholder support for the Bank.

We need social analysis to understand economic processes, and the impact of economic change. This is partly an issue of project quality: the social dimension affects project outcomes. It can help identify whether and how a project can contribute to development; it can help set realistic objectives; it helps to identify appropriate activities to meet objectives. It is also partly a duty of care: the Bank must avoid unintended adverse social impact. Social analysis reduces the risk of encountering unforeseen adverse consequences, and of negative impact.

There are similar reasons for doing environmental analysis: both to improve project quality and sustainability, and to avoid adverse impacts. The Bank ignored both environmental and social impact for most of its history. As a result, it came under damaging criticism for adverse environmental impact. This undermined support for the Bank. It belatedly improved environmental procedures, but too late to avoid lasting damage to the Bank, as well as to some borrowers.

\section{What Needs to be Done}

The Bank has so far responded piecemeal, with separate Operational Directives on different social issues, e.g. resettlement, indigenous peoples, gender. This sometimes is burdensome on Task Managers, and confusing for the Board, management, staff and clients alike. For example, it is ridiculous to mandate social assessment in relation to biodiversity, but not elsewhere. We need to consolidate and encapsulate all social issues into a single Operational Directives and document for doing the social analysis we need. I would hope that a Bank Operational Directive would make social analysis a mandatory part of the project preparation and appraisal. Note that I include gender in this. I do not think it helpful to separate this out from other social relations. Much as we lobbied hard to get an OD on gender, I would gladly rescind it in exchange for an overall OD on social assessment. 
In the Bank, we need a single central department, charged with developing the policy, monitoring its implementation, and promoting best practice. I commend the work of Gloria Davis, Michael Cernea and others for pioneering much of this in the Bank, but I have always been uncomfortable with having one Vice-President responsible for poverty, social policy, and gender, and another responsible for resettlement, indigenous peoples and so on. I suspect that this has contributed to the Bank's piecemeal approach. It certainly does nothing to help the Bank present a clear message on social issues.

But as in other disciplines, the bulk of the work needs to be done in the context of actual programmes and projects. That means that we need staff in the regions to provide social analysis for country programmes: planning the Country Assistance Strategy, undertaking ESW and policy dialogue, and designing and supervising operations.

In order to carry out this work, we will need more social analysis; something we have argued for in the Board for a long time, and in my role as a Personnel Committee member.

Too often, we have been dissatisfied with the management's response, which points to social analysts employed under various Trust Funds, including internal Trust Funds like the FIAHS fund. We have never been satisfied with this approach, even though we appreciate the specific contributions of these funds. Indeed, the UK has financed a Social Analyst slot until very recently, when Andrew Norton returned to ODA. But reliance on additional funds is a symptom that the activity is not yet regarded as a priority for regular budgetary resources. However we may get by in the meantime, we will not solve the skill-mix problem until we solve the budget problem: getting managers to allocate their budgets to hire social analysts as regular World Bank staff.

But let me sound a note of caution. If we take a historical perspective on the Bank, we can see that there have been successive phases of dominance by different disciplines. The IBRD was set up by bankers, who would review financial proposals. This quickly gave way to a Bank of engineers, who designed infrastructure projects, which are a lasting monument to their technical expertise. Eventually, the engineers gave way to economists, when it became clear that the client economies could not afford to maintain all this infrastructure. We still have now an economists' Bank. This is obvious from the relative numbers of economists versus other staff. This is emphasized by our central research department being called "Development Economics Vice Presidency," and our training institute as an "Economic Development Institute."

There may be some amongst you who look for the dawning of a new age, when the economists are dethroned by the social analysts. I do not expect this to happen, nor do I think it would be a good thing if it did happen. As I said at the beginning, the Bank is fundamentally about economic development. Economics will always be a core discipline at the Bank, though I think there are far too many macro-economists, when the business of the Bank is far more micro.

What is needed is not a change in the core discipline, but an end to hegemony by one discipline. We must avoid financially unsound loans, which do not build lasting 
infrastructure. It is what led to fine infrastructure, but which after being built could not be maintained. Equally, we must avoid economic reform programmes which are not socially sustainable, or projects, which hurt the poor they are trying to help. I fear that dominance by social analysts would lead to excellent participatory processes, but the activities might be economically and technically unsustainable, scarce resources might be wasted, and the debt might not get serviced. Instead, the Bank needs to become a truly multi-disciplinary organization.

Introducing social analysts into the Bank does not mean turning out the economists. It means finding a better balance between complementary skills. Let me say a little more about how this can be done.

\section{How to Achieve This}

In the Bank we see too much emphasis on preparing a blueprint, and then defending it against criticism, often even against the real-world critique that it is not working. The Board has become a kind of viva exam: at the end of the long months of writing the dissertation, the task manager defends it against a range of questions. If he acquits him or herself well, he or she sits back in satisfaction at a job well done. It can and should be a much more cooperative process, as I know from experience at the IMF Board. It is difficult to bring different disciplines into this way of working, since the project is framed within the context of the discipline from which the Task Manager comes. Too often, the economist is brought in to validate a design prepared by the engineer. Likewise, it would be a danger if the social analyst is brought in only to 'right a paragraph' on the project prepared only by the economist.

I have been glad to see efforts in many parts of the Bank to move away from this kind of project cycle. One element of this is the emphasis on participation: once we accept that we need the input of all stakeholders, we have made a huge leap in the direction of opening up the design and appraisal of the project. Stakeholders will raise social issues, whether we like it or not.

The second element is the process approach. Moving away from seeing a project as a blueprint helps open up the scope for responding to social realities.

The third element is multidisciplinarity. That means drawing together all the relevant professional perspectives and evaluation. If we can get social analysts 'onto the team', then they can play a constructive role, rather than being seen as another layer of criticism and review with which the task manager has to contend.

As a member of the Budget Committee, you would expect me to have given some thought to the cost of all this.

As I said earlier, this is a cost, which the Bank must accept on its regular budget, not palm off onto trust funds, whether internal or external. That is why we have not supported indefinite continuation of the FIAHS fund. However valuable the specific activities it has financed, it should be no more than a pump-priming exercise. Allowing it to become permanent will keep social analysis in the category of add-on, rather than internal core cost. The only way social analysis will get funded 
from the regular budget is if managers, as budget holders, see it as a priority for use of scarce resources.

The key to this is accountability. Jim Wolfensohn has rightly placed a lot of emphasis on this. So do I.

I fully support recent efforts to develop monitoring indicators of project performance. Task managers should be clearly accountable for the achievement of project objectives. The objectives should encompass social impact, which should be monitored during implementation and evaluated after project completion. Only when managers are held accountable for the development effectiveness and social impact of their projects will they take social analysis seriously. And that means investing resources in social analysis.

\section{Role of the Board}

I would like to hear from you how you think, as a Board member, I can help this process along, but let me offer a few initial thoughts.

We have seen increasing Board concern about social issues. With Jim Wolfensohn, we have a President who is strongly committed to social issues. The Task Force in which many of you are involved, provides an opportunity to present management and the Board with workable proposals. I'm sure that there is a lot of creative thinking going on at the moment as part of this process. Like Eveline Herfkens, I strongly advise you to explain to your management and to the Board why taking full account of social impact leads to better projects.

But again, let me inject a note of realism. What we are discussing is not all that novel, though it may be new to the Bank. Many donor agencies have incorporated social analysis into their work for many years. In the UK, ODA has had Social Development Advisers for nearly twenty years, and has had a separate Social Development Department and Chief Social Development Adviser for four years. Most importantly, it employs sufficient social analysts in its country departments to ensure that they are fully engaged in project teams and country strategy teams. I welcome the efforts that the Task Force is making to draw on this experience. So let us not go overboard in designing something new and untried. Let's simply aim, as a modest first step, to bring the Bank up to the industry standard.

Part of the reason I say this is that I am conscious that there is a lot of change going on in the Bank. Many staff, and some Executive Directors, may question whether this is an issue which we need to press ahead on now. We can convince them it is, if we propose something attainable. So we all have a role to play in persuading our colleagues that this is an issue which, like the environment, will not go away; that we ignore it at our peril; and that the result of neglect will be poo portfolio performance, and continued and justified external criticism.

Now, I will continue to play my part in the Board in emphasizing the importance of social issues, and holding management to account for the development effectiveness of the Bank's portfolio. But we all have a part to play in convincing managers of 
the contribution of social analysts to improving development effectiveness. It must not be seen as a special interest clamouring for attention. Instead, we must bring to managers' attention - whether from above or below-the contribution that social analysis can make to project quality, and to avoiding damaging impacts on the poor.

A final word. When people appear on talk-shows, they always have a book to promote. Some of you may have seen this already. It is a Guide to Social Analysis, prepared by ODA. To the professional social analysts amongst you, it may seem fairly basic. But its aim is to explain in practical ways how social analysis can contribute to project design and appraisal. It is required reading for all social analysts working on ODA projects. You may find it useful in your work, or may want to put it on the reading list of task managers you work with. There are order forms here, for anyone interested.

April 1996

Huw Evans trained as an economist and serving for many years with the UK Treasury, Huw Evans represented the United Kingdom on the World Bank Board between 1994-1997.

Open Access This chapter is licensed under the terms of the Creative Commons Attribution 4.0 International License (http://creativecommons.org/licenses/by/4.0/), which permits use, sharing, adaptation, distribution and reproduction in any medium or format, as long as you give appropriate credit to the original author(s) and the source, provide a link to the Creative Commons license and indicate if changes were made.

The images or other third party material in this chapter are included in the chapter's Creative Commons license, unless indicated otherwise in a credit line to the material. If material is not included in the chapter's Creative Commons license and your intended use is not permitted by statutory regulation or exceeds the permitted use, you will need to obtain permission directly from the copyright holder.

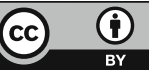

